Биљана Пајић

Универзитет у Београду

Филолошки факултет
UDC: 02:004.738.5

DOI: $10.18485 /$ dh.2015.1.ch14

\title{
УЛОГА САВРЕМЕНИХ БИБЛИОТЕКА У УПРАВЉАЊУ ЗНАЊЕМ
}

\section{Сажетак}

Последњих година се улога савремених библиотека све више из тачке медијатора знања помера у смеру управљања знањем и информацијама. Која је заправо улога библиотека у управљању знањем, шта она значи за будућност библиотека и у којој мери се одражава на рад у њима - питања су којима се бави овај рад.

У раду се, пре свега, појашњава термин управљања знањем, затим врсте знања, као и фазе кроз које оно пролази, посебно се осврнувши на минхенски модел управљања знањем.

Потом долази до делатности и улоге библиотека у 21. веку, које се под утицајем технолошких промена и достигнућа драстично мењају. Да ли књиге, библиотеке и библиотекари постају архаични предмети, места и занимања и лагано изумиру, или само са новим технологијама добијају нове форме, правце и перспективе?

Одговори на ова питања, представљени кроз примере неколико познатих дигиталних сервиса који се базирају на библиотекарском знању и информацијама које обезбеђују библиотеке, повезују библиотеке са појмом управљања знања према минхенском моделу.

Закључујемо да је међузависност библиотека и управљања знањем од велике важности за будућност библиотека.

Кључне речи: библиотека, електронска библиотека, електронско читање, управљање знањем, управљање информацијама

"Google can bring you back 100,000 answers. A librarian can bring you back the right one.

Neil Gaiman 
Шта је знање, како настаје и које врсте знања постоје?

Знање је у 21. веку можда и најважнији и највреднији капитал. Знање припада породици корпоративних добара која се константно увећавају, попут система управљања, идентитета бренда, информација о корисницима и репутације фирме. (Паскарела 37-40). Зато се управо многе фирме баве питањем прикупљања, складиштења, дељења и размене - једном речју - управљања знањем.

Да бисмо дефинисали управљање знањем, претходно морамо дефинисати само знање. Оно није ни податак нити информација, иако је повезано и саједним и са другим (Дејвенпорт и Прузак 4): „Knowledge is a fluid mix of framed experience, values, contextual information, and expert insight that provides a framework for evaluating and incorporating new experiences and information. It originates and is applied in the mind of knowers. In organizations, it often becomes embedded not only in documents and repositories but also in organizational routines, processes, practices, and norms."

Како и сами аутори наглашавају, ова дефиниција јасно приказује да знање није ни уредно нити једноставно. Оно представља мешавину различитих елемената; флуидно је, али истовремено и формално структурирано; интуитивно је, па стога и тешко за вербално формулисање или потпуно разумевање у границама логике (4).

Знање, према Дејвенпорту и Прузаку, настаје из информација, док информације настају из података. Да би информација постала знање, потребно је да се догоде четири процеса:

1. поређење - како се информација о датој ситуацији пореди са другим ситуацијама које познајемо;

2. последице - какве импликације има ова информација на одлуке и акције;

3. повезивање - у каквом је односу овај делић знања са осталим;

4. конверзација - шта други мисле о овој информацији (5).

Већ из горенаведене дефиниције препознајемо две врсте знања које се најчешће наводе: тацитно и експлицитно. Смит експлицитно знање дефинише као „академско знање или „know what", описано формалним језиком у штампаним или електронским медијима, а често је за- 
сновано на установљеним радним процесима“. Тацитно знање, с друге стране, представља „практично знање које се оријентише на конкретну акцију", а најбоље га дефинише енглески израз „know-how". Стиче се личним искуством, ретко се отворено изражава, а веома је налик интуицији (314). Укратко речено, експлицитно знање је материјализовано, записано знање, док је тацитно искуствено, интуитивно.

Немачки израз за експлицитно знање био би Informationswissen, тj. знање које се базира на информацијама, док се за тацитно знање у немачком језику употребљава реч Handlungswissen и означава знање које се базира на радњи. Према минхенском моделу управљања знањем, знање се у зависности од перспективе креће између информације и радње. Важну улогу притом играју следеће особине:

Експлицитно знање:

- може постојати појединачно;

- може се преносити такво какво јесте;

- може бити довољно и без контекста;

- ескплицитним знањем се може изградити тацитно;

- „поседовање“ експлицитног знања може се доказати репродукцијом;

Тацитно знање:

- може се наћи само у смисленим значењима;

- мора се конструисати као мрежа смислених веза;

- увек је део неког контекста;

- применом тацитног знања, знање се трансформише у делање;

- само применом тацитног знања у новим контекстима могуће је доказати „конструисање“ тацитног знања (Рајнман-Ротмајер 15).

У средишту минхенског модела управљања знањем налазе се четири процеса кроз која знање пролази на путу између информације и радње: репрезентација, употреба, комуникација и генерисање знања (Рајнман-Ротмајер 22-26). У процесу репрезентације знање постаје видљиво, досежно, приступачно и боље разумљиво. У процесу употребе знање постаје примењиво и прераста у делање. Про- 
цес комуникације односи се на размену знања, његово дељење и умрежавање, покретање знања такода је то кретање могуће посматрати. Последњи у низу, процес генерисања, подразумева прерађивање сирове информације у релевантно знање и изграђивање новог знања.

\section{Шта је управљање знањем?}

Када су у питању дефиниције управљања знањем, тешко је определити се за једну, јер их је за релативно кратко време постојања дисциплине која се њиме бави настало веома много различитих. Поједини научници чак свесно одбијају да га дефнишу, сматрајући да је сувише комплексно да би се „упаковало“ у једну реченицу. За многе друге то, ипак, није разлог за одустајање од тражења праве дефиниције.

Једну од њих дао је ЛаБранш, објаснивши управљање знањем као процес трансформисања информација и интелектуалних добара у трајну вредност. Управљање знањем повезује људе са знањем које им је потребно и подстиче на предузимање одређене активности у тренитку када им је знање потребно (Хокинс 3). Има и једноставнијих дефиниција, које управљање знањем дефинишу као грану менаџмента која тежи да унапреди организацијску обраду знања (Фајерстон 70), а већина аутора усаглашена је у тврдњи да је управљање знањем у корпоративном контексту важно оруђе у трци са конкуренцијом.

Да би управљање знањем испунило своје потенцијале, потребно је комбиновати две горенаведене врсте знања. Индивидуално искуствено - тацитно - знање треба применити на експлицитно изведене процесе да би право знање било доступно правим људима у право време (Кидвел, Линде и Џонсон 1-24).

Проблем настаје у организацији знања. Експлицитно знање само по себи у том контексту није представљало проблем - оно је, самим тим што је записано и физички сачувано, погодно за организовање и каталогизовање. Изазов представља пре свега прикупљање, а потом и записивање, организовање и размена тацитног знања.

Са појавом Интернета се, међутим, сусрећемо са новом димензијом. Због, како је Хокинс назива, „експлозивне“, или тзв. 
bottom-up природе веба, експлицитно знање се прилично тешко усваја. Тацитним је, са друге стране, веома тешко овладати, јер је такорећи затрпано међу линковима који упућују на друге странице, базама података и публикацијама (4).

Минхенски модел управљања знањем нуди шему којом приказује како знање кружи од информације до радње, одн. од експлицитног до тацитног, кроз четири већ поменута процеса. Од процеса репрезентације до процеса употребе знање пролази кроз фазу информације, тј. експлицитног знања, док у другом смеру између ова два процеса стоји фаза радње, тј. тацитног знања. И процеси комуникације и употребе такође су упућени један на другог, као и процеси генерисања и репрезентације. Када у радном процесу препознамо одређени проблем или ситуацију и поставимо циљ за разрешење, предузимамо одређену радњу која нас кружењем знања доводи до информације. Наставком кретања знања кроз наведене фазе, долазимо до нове радње која нам доноси решење проблема или ситуације.

\section{Библиотеке у ери Интернета - њихова делатност и улога}

Дигиталне технологоје драматично мењају досадашњи, тзв. традиционални модел библиотека. Како би опстале, библиотеке имају задатак да се адаптирају, тако што ће с једне стране модификовати, допунити или одбацити неке од постојећих сервиса, а с друге стране задржати суштинске вредности које одређују њихову улогу, у академском окружењу (Хокинс 1), али и образовном систему уопште.

Некада, мада не толико давно, библиотеке су биле једина места где је било могуће пронаћи информације и проширити знање, нека врста острва са благом, које се мери у знању и информацијама. Данас је наша свакодневица дословно преплављена информацијама. Долажење до њих више не представља проблем. У том изобиљу, проблем је издвојити релевантне, а уз то и проверене информације. Самим тим, задатак библиотека није више само да прикупљају, складиште и каталогизују знање, већ, како наглашава Хокинс, и да процењују његову аутентичност и валидност. 
Улога Интернета и доступност информацијама коју исти омогућава често се изједначава са улогом библиотека. Истина је да су могућности које нам Интернет пружа практично бескрајне, али управо се у томе крије проблем - бескрај је немогуће сагледати, самим тим и организовати, претражити - речју, искористити његов пун потенцијал.

Грифитс наглашава потребу да разумемо Интернет и чињеницу да га не можемо изједначити са библиотеком, али и да је такво погрешно схватање све чешће, па је неопходно да се суочимо са тим проблемом: „It is imperative that we understand the Web and the ways it is not a library. But the Web, and whatever universaly available electronic information system follows it, must be reckoned with, because an everlarger population of our world is assuming that it replaces the library. We must address all the concerns the Web raises, find ways to compensate for its lacks, and reinforce the role of the library. (246)"

Подаци који се налазе на Интернету нису каталогизовани нити систематизовани, не постоји никакав регистар свих информација које Мрежа крије, а евалуација тачности и релевантности информација, уколико и постоји, није поуздана јер је често условљена маркетиншким или каквим другим циљевима. У ери Веба 2.0 - интернет-сервиса друге генерације, који се заснивају на понуди садржаја специфичној за сваког појединачног корисника, а на основу његових претходних претрага - не можемо ни говорити о објективној слици понуде на Интернету: она је за сваког од нас постала другачија у зависности од тога какве смо странице претходно посећивали, шта смо „лајковали“ или „ритвитовали“ на друштвеним мрежама или ко нам се налази на листи пријатеља. Управо зато није могуће улогу Интернета изједначити са улогом библиотеке, јер библиотечки посао, поред систематизовања знања и информација, укључује и њихову селекцију и евалуацију.

У међувремену су се на Интернету појавили различити сервиси који обављају управо ове функције, али само у ограниченом окружењу. Један од одличних примера је „Гугл академик“ (енг: Google Scholar), сервис за претраживање академских и научних књига, радова и чланака - који су у неким случајевима представљени само као мета-подаци, а у другим као потпун текст. Овај сервис је доступан од 2004. године, а у мају 2014. године процењено је да обухвата око 160 милиона докумена- 
та (Ордуња et al.), а од тога веома значајан проценат британских и америчких академских чланака. Веб-индексери овог сервиса претражују архиве највећих и најпознатијих академских издавача и универзитетских часописа попут IEEE, ACM, Macmillan, Wiley, University of Chicago, њихових дигиталних хостова попут HighWire Press, MetaPress, Ingenta, друштава и других академских организација, као и владиних агенција попут American Physical Society, National Institute of Health, NOAA и различитих сервера попут arXiv.org, Astrophysics Data System, RePEc и CiteBase (Јаско 209). „Гугл академик“ нам нуди неколико начина да препознамо вредност текста који смо пронашли. Један од њих је број који показује колико пута је исти цитиран у другим научним радовима доступним на истом сервису. „Гугл академик“ узима у обзир и оцене самог аутора, али и публикација у којима се чланак појављује, користећи посебан алгоритам (About Google Scholar). Упркос појединим критикама, овај сервис је прилично поуздан и веома користан за академску заједницу. Представља сјајан пример систематизовања онлајнподатака у сврху ефикасног истраживања.

Лаичким очима деловало би да међу оваквим сервисима традиционалним библиотекама полако истиче време. То, међутим, није тачно - овакви сервиси не би били ни могући без информација које им обезбеђују библиотеке. Документа која тим путем проналазимо заправо припадају архивима академских и других библиотека, оне су те које их објављују и чине доступним. Такође, за структурирање једног оваквог сервиса потребна су знања из области библиотекарства, књижарства и академског писања.

\section{Дигитализација као будућност библиотека}

Поред важне улоге које имају у структурирању академских сервиса на интернету, савремене библиотеке своју будућност виде и у дигитализацији књига и докумената и увођењу електронских библиотека у своју понуду, а притом на тај начин играју веома важну улогу у управљању знањем.

Дигитализовање је, међутим, веома скуп процес. Осим скупих хардверских и софтверских елемената, оно захтева и при- 
личан број радних сати, често у посебним условима, уколико се ради о дигитализацији старих и ретких књига. Стога су се пројекти дигитализације обављали испрва само у оквиру академских библиотека, и то у колаборацији са музејима, народним библиотекама и другим институцијама које имају издашније буџете. Данас се, међутим, све више јавних библиотека прикључује оваквим колаборативним пројектима (Фабунми 24).

Један од најпознатијих примера свакако је портал Europeana. Овај портал настао је 2008. године, а финансира се од стране програма Европске комисије. Обухвата низ пројеката дигитализације књига, архивских докумената, слика, филмова, музејских експоната и других објеката који представљају европску културну баштину, а чији број досеже готово 40.000.000. Свој допринос овим пројектима до сада је дало преко 3.000 библиотека и других институција. Осим према формату, језику на коме је дат опис документа, години издања, земље порекла и институције која документ ставља на располагање, резултате претраге на овом порталу могуће је претражити и према лиценцама за ауторска права, па тако корисник увек има јасну информацију о својим правима на различите начине коришћења документа.

Europeana својим примером јасно приказује улогу библиотека у управљању знањем. То најбоље видимо кроз анализу стратешког плана за период од 2011. до 2015. године. Наиме, у свом стратешком плану Europeana наводи четири путање:

1) прикупљање-изградити отворен и поуздан извор за садржаје европске културне баштине;

2) подршка - подржати сектор културног наслеђа путем трансфера, иновације и заступања знања;

3) дистрибуција - начинити културно наслеђе доступно корисницима где год да су у било ком тренутку;

4) мрежавање - развити нове начине на које корисници могу да учествују у свом културном наслеђу.

Стратешки циљеви за период од 2015. до 2020. године се нешто разликују, иако је уопштени циљ који из њега проистиче остао непромењен - доступност, приступачност и размена знања, али и тежња да овај портал прерасте у платформу која ће наставити да се изграђује и побољшава. У новом стратешком плану наводе се три приоритета: 
1) побољшање квалитета података;

2) отварање приступа подацима;

3) стварање креативне вредности за партнере.

Ако мало боље погледамо, у првом стратешком плану можемо препознати фазе кроз које знање пролази према већ поменутом минхенском моделу управљања знањем.

Прва фаза, фаза репрезентације, одговара првом стратешком циљу портала Europeana - прикупљањем објеката европске културне баштине и стављањем истог на располагање корисницима, знање постаје видљиво и приступачно. Ово такође одговара првом приоритету у новом стратешком плану - побољшањем квалитета података постиже се њихова приступачност и доступност.

Фаза употребе се у минхенском моделу управљања знањем односи на примену знања, коју на примеру првог стратешког плана препознајемо у подршци трансферу знања и истраживањима, која проистичу управо из коришћења података стављених на располагање путем портала.

Фаза комуникације у минхенском моделу практично се у потпуности поклапа са циљем дистрибуције културног наслеђа корисницима: крајња идеја и једног и другог крије се у размени и тзв. „кретању“ знања. Друга тачка новог стратешког плана - отварање приступа подацима такође се може приписати овој фази, јер само отвореним приступом се заиста може подстаћи ефикасна комуникација знања и идеја.

Минхенски модел нас напослетку доводи до фазе генерисања, која се односи на прерађивање сирових информација у релевантно знање, конструисање знања и стварање нових и иновативних идеја. Ова фаза умногоме одговара стратешком циљу умрежавања и откривања нових начина за учествовање корисника у свом културном наслеђу, јер само на тај начин из већ понуђеног знања могу настати нове и оригиналне идеје, али и трећој тачки новог стратешког плана - стварању креативне вредности за партнере, тј. подстицању стварања креативних идеја.

Када су овакви пројекти у питању, из перспективе минхенског модела управљања знањем улога библиотека у овим процесима најпре се базира на фази репрезентације, тј. стављања експлицитног 
знања на располагање корисницима. Многе библиотеке су, међутим, у своју понуду већ уврстиле електронске библиотеке и тим путем знатно активније учествују у управљању знањем.

Нидере, Штефенс и Хемје описују улогу дигиталне библиотеке називајући је „посредником између информационих потреба корисничке заједнице и доступног садржаја“ (446). Предселекцијом релевантног садржаја, његовим структурирањем у складу са заједницом којој су намењени, обогаћивањем додатним информацијама и мета-подацима, а на крају и понудом библиотечких сервиса попут анотације, омогућавања поновног коришћења докумената и др, дигиталне библиотеке учествују директно или индиректно у сваком од четири процеса минхенског модела управљања знањем.

Репрезентацијску и употребну фазу покривају самом дигиталном понудом и њеним одговарајућим структурирањем. Када су у питању фазе комуникације и генерисања, према Маркионинију и Мауреру библиотеке - било традиционалне или електронске - играју веома битну социјалну и интелектуалну улогу умрежавајући људе и идеје и нудећи интердисциплинарни поглед на знање. Дигиталне библиотеке, према томе, проширују те аспекте независно од физичке доступности, радног времена и сличних фактора. Стога је једна од њихових најзначајнијих предности то што повезују кориснике чији је циљ формално учење са онима који теже неформалном, али и онима који су ту због професионалног усавршавања (Маркионини и Маурер 68). На тај начин играју важну улогу у процесу комуникације и генерисања знања, што ће рећи да покривају све четири фазе минхенског модела, па самим тим активирају како експлицитно, тако и тацитно знање.

\section{Управљање знањем у библиотекама} на примеру еБиблиотеке Goethe-Instituta

еБиблиотека је дигитална понуда библиотеке Goethe-Instituta. Ова услуга омогућава корисницима да на одређено време позајме дигиталне медије, као што су е-књиге, е-аудио или е-новине тако што их једноставно преузму из еБиблиотеке.

Понуду електронске библиотеке Goethe-Instituta омогућила је фирма divibib GmbH из Визбадена у Немачкој, ћерка-фирма 
предузећа ekz.bibliotheksservice GmbH. Фирма divibib од 2007. године нуди једну од водећих платформи електронских библиотека, под називом Onleihe и тренутно броји преко 1.900 библиотека међу својим клијентима. Ова платформа се користи на нивоу целе Немачке од стране свих већих јавних библиотека, али и у библиотекама у Данској, Белгији, Италији, Лихтенштајну, Аустрији и Швајцарској. Поред уобичајене понуде путем веб-страница библиотека које користе услуге фирме divibib, псотоји могућност коришћења бесплатних апликација за Android и iOS платформе.

Мрежа Goethe-Instituta увела је у своју понуду електронску библиотеку 2011. године, а већ у тој фази су се прикључиле и неке од библиотека из региона југоисточне Европе. еБилиоткеа Goethe-Instituta располаже тренутно са 14.893 јединице, које обухватају белетристику, књиге за децу и омладину, приручнике и уџбенике из различитих стручних области, као и музику и аудио-књиге. Тренутно су у понуди електронске књиге и часописи у форматима: pdf, ePub и .acsm, као и аудио-материјали (музика одн. аудио-књиге) у формату .wma. У плану је и увођење филмске понуде у оквиру еБиблиотеке. Овај фонд доступан је свим библиотекама Goethe-Instituta које су укључене у мрежу електронских библиотека, али се услови коришћења разликују од института до института. За разлику од већине других, београдски Институт омогућује својим корисницима бесплатно коришћење овог сервиса, баш као и када је у питању понуда „папирне“ библиотеке.

Корисници се пријављују попуњавајући формулар који се налази на веб-страници Goethe-Instituta у Београду, наводећи своје основне податке, попут имена, презимена, датума рођења, адресе, броја телефона и броја чланске карте библиотеке Goethe-Instituta, уколико је имају. Ова пријава у библиотеку стиже у форми мејла, а библиотекар потом са свог налога на порталу Mein goethe.de генерише јединствени активациони код, који уз упутство за коришћење у ПДФ-формату путем мејла шаље кориснику. Корисник потом, уколико то није раније учинио, отвара профил на порталу Mein goethe.de, где у одељку „еБиблиотека“ уноси добијени активациони код. Тако је налог активиран у трајању од једне године. По истеку овог периода, корисник се на исти начин може поново пријавити. 
Фонд еБиблиотеке могуће је претражити једноставним системом претраге, или прелистати по категоријама на које је подељен. Када корисник пронађе тражени медиј, потребно је да га прво „стави у корпу", где може одабрати одговарајући формат и преузети датотеку. Враћање позајмљених датотека није потребно. По истеку рока за изнајмљивање, датотека се једноставно више не може отворити.

Goethe-Institut у Београду располаже понудом еБиблиотеке од јануара 2014. године. Од тада - за две године постојања - генерисан је 1.531 активациони код, што чини готово 9\% укупног броја у региону југоисточне Европе. еБиблиотеку тренутно користи 340 активна корисника из Србије, што је 15,4\% укупних активних корисника из југоисточне Европе. У 2014. години су корисници из Србије путем еБиблиотеке Goethe-Instituta изнајмили 1.193 медија, док је овај број у 2015 порастао за чак 71,9\% и достигао број од 2.051 изнајмљеног медија. У 2014. години се за коришћење пријављивало 2,22 корисника по дану, док је просек у 2015. години нешто мањи: 1,81.

У осврту на минхенски модел управљања знањем, четири фазе кроз које знање пролази могу се препознати и у делатности еБиблиотеке Goethe-Instituta. Наиме, фаза репрезентације огледа се управо у самој понуди електронских медија. Фазу употребе препознајемо у структури еБиблиотеке, која је прилагођена просечном кориснику Goethe-Instituta - еБиблиотека се, као и традиционална библиотека Goethe-Instituta, најчешће користи за читање електронских новина и часописа, коришћење материјала за учење немачког језика, читање белетристике и слушање аудио-књига. Самим тим је ова понуда најизраженија, а на почетној страници су најтраженије области посебно истакнуте, како би корисници што брже и једноставније дошли до њих. Садржај еБиблиотеке је обогаћен мета-подацима, тако да се сами медији могу даље употребљавати, а омогућене су и функције попут проналажења сличних медија путем кључних речи, које такође подстичу употребну фазу кретања знања. Комуникацијска фаза знања огледа се пре свега у доступности библиотеке 24 часа дневно 7 дана у недељи било где, где постоји Интернет-конекција. Понуда апликација за различите платформе (Android, iOS) такође је део комуникацијске фазе, као и могућност коришћења различитих формата. Као део ове фазе препознали смо и могућност оцењивања 
медија и препоручивања медија пријатељима. С обзиром да се овде ради о библиотеци која није академског или истраживачког типа, фаза генерисања - стварања новог знања - није у заступљена у значајној мери. Као једну од функција која припада овој фази ипак бисмо истакли различите анкете које спроводи како фирма divibib, тако и Goethe-Institut, у циљу добијања информације о корисничком доживљају и евентуалном унапређивању истог.

\section{Захтеви дигиталног окружења у контексту библиотекарске делатности}

У претходним поглављима приказане су функције савремених, пре свега дигиталних, библиотека, као и промене у библиотечкој понуди настале под утицајем нових технологија. Осврнућемо се напослетку на промене у делатности самих библиотекара које ново, дигитално окружење са собом носи.

У једном истраживању међу америчким библиотекарима из области дигиталног библиотекарства у академским и истраживачким библиотекама, под покровитељством Асоцијације за образовање у области библиотекарства и информатике, утврђена је структура запослених на овим позицијама, њихове најважније активности, затим компетенције које они већ имају, као и оне за којима се показује потреба.

Резултати анкете, спроведене међу 48 испитаника, показују да је рад у дигиталном библиотекарству колаборација између области које сежу од компјутерских система до традиционалних библиотечких функција. Запослени су махом млади, а чини се да је новим генерацијама овај посао веома привлачан. Главни задаци запослених везани су за област менаџмента, као и за Интернет.

Истраживање је потврдило претпоставке да на овим позицијама веома велику улогу играју личне вештине (енг. soft skills), нарочито због колаборативне природе посла, где до изражаја долазе вештине комуникације и управљања. Такође, због константног напретка на пољу технологије, дигитално библиотекарство се мења у сличном ритму, па су библиотекарима у овој области неопходне вештине прилагођавања и спремности на учење и усавршавање (Чои и Расмусен). 
Ови подаци указују на чињеницу да библиотекарска делатност постаје вишедимензионална - поред традиционалног знања из области библиотекарства и односа са корисницима, неопходна је и едукација на пољу нових технологија, менаџмента, међуљудских односа и тимског рада.

Адаптација запослених на дигитално окружење свакако је неопходна, али према многим стручњацима неопходно је прилагодити и начин на који се знањем барата. Хокинс описује своју идеалну визију будућих библиотека универзалним електронским приступом колективном корпусу традиционалних библиотека, као и укључивањем материјала са интернета и других врста тацитних информација. Сматра да знање - а пре свега све образовне и истраживачке публикације - треба да буде доступно свима, без обзира на географски положај или статус (4-5). 2000. године, у време писања Хокинсовог чланка, још увек није постојао јасан план како до тога доћи. Данас, 15 година касније, располажемо са неколико великих пројеката, који подстичу отворени приступ знању, а тенденција ка отвореном приступу је све јача, нарочито у академској заједници. И даље, међутим, постоје правни и економски проблеми, са којима се ова идеја суочава и за које још увек није пронађено адекватно решење.

\section{Закључак}

Управљање знањем је све важнија област у глобалном смислу, а у великој мери обележава и будућност бибилиотекарске делатности. Да би савремене библиотеке задржале статус институција у којима је могуће пронаћи релевантно знање и информације, веома је битно да се посвете изучавању ове области.

У време када смо захваљујући интернету преплављени разним, а често и нетачним информацијама, улога библиотека није више само да обезбеди саме информације, већ и да издвоји оне које су релевантне и поуздане. Будућност библиотека, међутим, не лежи у некој врсти „борбе“ против Интернета и едукације корисника о томе колико подаци које на Мрежи свакодневно проналазимо могу 
бити непоуздани и нетачни. Будућност библиотека крије се заправо у коришћењу свих потенцијала Интернета у сврху функционалног управљања знањем. У раду смо представили неколико начина на који библиотеке то могу учинити.

Један од њих је учествовање у снабдевању знањем и подацима различитих онлајн-сервиса, који омогућују претрагу академских чланака, научних радова и др, што смо видели на примеру сервиса „Гугл академик".

Значај библиотека се у том смислу огледа и у дигитализацији књига и других докумената, које потом стављају на располагање јавности. Ова делатност је, међутим, прилично обимна и захтевна у сваком смислу, а пре свега финансијском. Стога се најчешће обавља у колаборацији са великим институцијама, а у оквиру великих међународних пројеката, који се финансирају из буџета специјално намењених за ту сврху. Пример таквог пројекта, који је заживео широм Европе и развија се и надаље дали смо у осврту на портал Europeana.

У оба горенаведена случаја, библиотеке у процесима управљања знањем учествују тек површно, стављајући знање на располагање. Међутим, увођењем сопствених електронских понуда, попут електронских библиотека, библиотеке постају средиште ових процеса - обављају предселекцију и структурирање, обогаћују садржај мета-подацима и нуде библиотечке сервисе за своје кориснике. Самом чињеницом да су електронске библиотеке доступне на било ком месту у било које време омогућују далеко функционалнију размену, али и генерисање новог знања, него што је то био случај са традиционалним библиотекама. Овакав пример имамо у библитокама GoetheInstituta, међу којима је и његов београдски огранак. Посматрајући електронску понуду библиотека Goethe-Instituta кроз призму минхенског модела управљања знањем, могуће је препознати њене предности и, усуђујемо се рећи, неопходности у савременом друштву.

Увођењем електронске понуде, учествовањем у великим међународним, али и мањим локалним пројектима дигитализације и тенденцијом ка отвореном приступу знању библиотеке ће осигурати свој пут у будућност. Пополочавајући овај пут знањима из области 
нових технологија и менаџмента, али и тимског рада и међуљудских односа, савремене библиотеке ће сасвим сигурно бити у самом врху академске и образовне заједнице.

\section{Литература}

Choi, Youngok, and Edie Rasmussen. „What Is Needed to Educate Future Digital Librarians? A Study of Current Practice and Staffing Patterns in Academic and Research Libraries" D-Lib Magazine, September 2006, Volume 12 Number 9 (2006)

Davenport, Thomas $\mathrm{H}$, and Lawrence Prusak. „Working Knowledge: How Organizations Manage What They Know", ACM:Ubiquity (2000): 4. https://online.ist.psu.edu/ sites/ist852hellar/files/readings/T1-Chapter1.pdf 10.09.2015.

Fabunmi, Beatrice Ayodeji, Matthew Paris and Martins Fabunmi. „Digitization of Library Resources: Challenges and Implications For Policy and Planning" International Journal of African \& African American Studies, Vol. V, No. 2, Jul 2006 (2006)

Fireston, Joseph W. and Marc W. McElroy. "Key Issues in the New Knowledge Management", Burlington, MA: Elsevier Science (2003): 70.

Griffiths, Jose-Marie. "Why the Web is Not a Library" The Mirage of Continuity: Reconfiguring Academic Information Resources for the 21st Century (Ed. Brian L. Hawkins and Patricia Battin), Council on Library and Information Resources (CLIR) and the American Association on Universities (AAU), Washington, DC (1998): 246.

Hawkins, Brian. „Libraries, Knowledge Management and Higher Education in an Electronic Enviornment" (2000): 4. http://files.eric.ed.gov/fulltext/ED452865.pdf

Jascó, Péter: „Google Scholar: the pros and the cons" Online Information Review April 2015, University of Hawaii, Manoa, Hawaii, USA (2005)

Kidwell, Jillinda J, Karen Vander Linde and Sandra J. Johnson. „Applying Corporate Knowledge Management Practices in Higher Education“ Information Alchemy: The Art and Science of Knowledge Management. (Ed. Gerald Bernbom), EDUCAUSE Leadership Strategies, No. 3, Jossey-Bass, San Francisco (2000): 1-24.

LaBranche, Gary A. „Knowledge Management: The Killer App for the 21st Century“, A. CAE, Government Relations (2000)

Marchionini, Gary and Hermann Maurer. „The Roles of Digital Libraries in Teaching and Learning" Communications of the ACM (1995)

Niderée, Claudia, Ulrike Steffens and Matthias Hemmje. „Towards Digital Library Mediation for Web Services" in: Proceeding of EurAsia-ICT 2002, 1st EurAsian conference of advances in information and communication technology, Shiraz, Iran

Orduña-Malea, E, J.M. Ayllón, A. Martín-Martín and E. Delgado López-Cózar. „About the size of Google Scholar: playing the numbers", Granada: EC3 Working Papers, 18: 
23 July 2014 (2014) http://arxiv.org/ftp/arxiv/papers/1407/1407.6239.pdf Pascarella, Perry. „Harnessing knowledge“, Management Review 86.9 (1997)

Reinmann-Rothmeier, Gabi. „Wissen managen: Das Münchener Modell“, Ludwig Maximilians Universität München Empirische Pädagogik und Pädagogische Psychologie (2000)

Smith, Elisabeth A. „The role of tacit and explicit knowledge in the workplace“; y: Journal of Knowledge Management, Volume 5, Number 4 (2001)

\section{Остали електронски извори:}

About Google Scholar; https://scholar.google.com/scholar/about.html 14.09.2015. http://www.europeana.eu/portal/ ; 15.09.2015.

http://pro.europeana.eu/about-us/factsfigures ; 15.09.2015.

http://pro.europeana.eu/share-your-data/become-a-data-provider ; 15.09.2015.

http://pro.europeana.eu/files/Europeana_Professional/Publications/Strategic\%20 Plan\%202011-2015\%20\%28colour\%29.pdf ; 15.09.2015.

http://pro.europeana.eu/files/Europeana_Professional/Publications/Europeana\%20 Strategy\%202020.pdf ; 15.09.2015.

http://www.goethe.de/ins/cs/sr/bel/kul/bib/onl.html ; 20.09.2015.

http://www.onleihe.net/unternehmen.html ; 20.09.2015.

www2.onleihe.de/goethe-institut/ ; 21.09.2015.

http://www.unshelved.com/2007-06-30; 18.09.2015.

\section{Biljana Pajić}

University of Belgrade

Faculty of Philology

\section{THE ROLE OF MODERN LIBRARIES IN KNOWLEDGE MANAGEMENT}

\section{Summary}

In the last few years the role of modern libraries moves more and more from the point of knowledge mediator to the direction of knowledge and information management. What is the role of libraries in knowledge management, what it means for the future of libraries and how shall it affect the library work - those are the questions that this paper tries to answer. It'll also take a look at the role of electronic media and digital 
libraries in this context and question the connection between the development of the informational technologies and knowledge management in libraries.

Key words: Knowledge management, library, e-library, e-reading, information management 